\title{
A LABORATORY TECHNIQUE TO SCREEN SEEDLING EMERGENCE OF SORGHUM AND PEARL MILLET AT HIGH SOIL TEMPERATURE
}

\author{
By P. SOMAN and J. M. PEACOCK \\ International Crops Research Institute for the Semi-Arid Tropics (ICRIS.AT), \\ Patancheru, Andhra Pradesh 502 324, India
}

(Accepted 23 January 1.98.5)

\begin{abstract}
SUMMARY
Apparatus was built to screen sorghum and pearl millet for seedling emergence through a hot soil surface. Seeds were sown in soil in long clay pots arranked in a steel water tank so that the top $7 \mathrm{~cm}$ of the pots was above the water level. The soil in the pots was heated with infra-red lamps fitted to a frame above the tank. By adjusting the height of the frame the temperature of the soil could be changed. The system allows emerging plumules to be subjected to high soil temperatures (up to $50^{\circ} \mathrm{C}$ ) but without water stress. Both crops exhibited genotypic differences in emergence.
\end{abstract}

In India, West Africa and southern Africa soil surlace temperatures in farmers' fields commonly exceed $45^{\circ} \mathrm{C}$ and temperatures as high as $60^{\circ} \mathrm{C}$ have occasionally been measured (Soman et al., 1981; ICRISAT, 1983; Peacock, 1977; Peacock and Ntshole, 1976). Soil temperatures above $45^{\circ} \mathrm{C}$ inhilit the emergence of seedlings in sorghum and pearl millet resulting in poor crop stands (Mustain, 1981; Soman, 1981; Garcia-Huidobro et al, 1982; Peacock, 1982; Wilson et al., 1982; Peacuck and Heinrich, 1984). These experiments demonstrated considerable variability among sorghum and pearl millet lines for secdling emergence at high temperature. As emphasized by Wilson et al. (1982) it is important to identify lines of sorghum and pearl millet, two major cercals of semi-arid regions, that will emerge at high soil temperature.

Genotype response to temperature is difficult to study in the ficld because soil temperature varies with the moisture status of the soil and the system becomes even more complex if a crust develops on the soil (Soman et al., 1984). Measurements of germination in constant temperature incubators arc not necessarily relevant to the field where soil temperatures vary diurnally. Our observations with selected sorghum lines have shown that material which fails to germinate in incubators at $40^{\circ} \mathrm{C}$ will germinatc and emerge when sown in soil of the same mean temperature.

Various techniques have been used to study the germination and emergence response of cereals to high soil temperature (Scheuring et al., 1978; Wilson et

ICRISAT Joumal Article 459.

The use of a trade name does not imply endoruement of that product by ICRISAT. 
al., 1982; Buckle and Grant, 1974). Scheuring et al. (1978) recorded germination of sorghum kept in wet sand in a warm water bath at a constant temperature for 72 hours; the seeds were thus exposed to a continuous high temperature (maximum of $40^{\circ} \mathrm{C}$ ). Wilson et al. (1982) varied soil temperature using two different surface colourants, charcoal and kaolin, in small plots. Though the temperature regime obtained with their technique was adequate for screening for emergence, the water status of the soil could not be controlled. Similarly Buckle and Grant (1974), who grew maize seedlings in soil in dark incubators, did not replenish the soil moisture during the course of the experiment. Mustain (1981) observed an effect of differing moisture levels on germination at high temperatures. In all these experiments it was diflicult to study the effect of temperature alone on scedling emergence because of interactions between water status and soil surface conditions. This paper describes a tech. nique used to examine the effect of high soil surface temperature on selected lines of sorghum and pearl millet where soil water was not limiting and surface crusts absent.

\section{MATERIALS AND METHODS}

\section{Apparatus}

Porous clay pots, $30 \mathrm{~cm}$ in length and $10 \mathrm{~cm}$ in diameter, were filled with sieved top soil (0-20 cm depth) from an Alfisol field (Udic Rhodustalf, Patancheru scries). The soil type was loamy sand, its principal components being coarse sand (particle size $200-2000 \mu \mathrm{m}$ ) $53 \%$, finc sand $(20-200 \mu \mathrm{m}) 25 \%$ and clay $(<2 \mu \mathrm{m}) 16 \%$. The pots were placed in a $183 \times 92 \times 38 \mathrm{~cm}$ steel water tank so that only the top $7 \mathrm{~cm}$ of the pots was above the water level. The soil surface was $2 \mathrm{~cm}$ below the mouth of the pot. Thirty-six pots were placed in the tank. The surface of the water was covered with thoating white plastic balls to reduce evaporation.

The soil in the pots was heated with infra-red lamps $(240-250 \mathrm{~V}, 250 \mathrm{~W}$, Phillips, Type IRR) fitted to a frame above the tank. Ten lamps were placed in two rows, $40 \mathrm{~cm}$ apart. The temperature of the soil surface could be altered by varying the height of the frame above the soil surface, to obtain temperatures of $35,40,45$ and $50^{\circ} \mathrm{C}$ measured at $2 \mathrm{~cm}$ below the soil surface. The design is simple and the total cost of the unit approximately one tenth that of a com. mercial growth chamber.

\section{Operation}

Seeds sclected for uniformity in size were sown at precise depths $(3 \mathrm{~cm}$ for millet and $5 \mathrm{~cm}$ for sorghum) at the rate of ten per pot.

The infra-red lamps were automatically switched on at 0800 Indian Standard Time (IST) and switched off at 1800 IST by a time clock. Soil temperature was measured every two hours in each pot using copper-constantan thermocouples and a millivolt meter (Comark Instruments, UK). Temperature of the soil sur- 
face was difficult to measure accurately as the thermocouple junction was heated by radiation. The junctions were therefore buried at a depth of $2 \mathrm{~cm}$ in the soil and the output used to indicate the surface temperature. Soil temperatures at 5,10 and $15 \mathrm{~cm}$ depths were also measured in a few cases.

Water was added to the tank daily to maintain a constant level, ensuring that the wet soil column $(25 \mathrm{~cm}$ long) in the pots provided a steady water supply for the seedlings while allowing them to be affected by the temperature of the soil. The soil water content in the pots was determined gravimetrically. A small soil tube $(2 \mathrm{~cm}$ diameter $)$ was used to take $10 \mathrm{~cm}$ soil samples from two to four days after sowing (DAS). Samples were dried at $110^{\circ} \mathrm{C}$ and the percentage moisture cstimated.

\section{Experimental treatments}

Threc experiments using this technique are described. In Experiment I 24 sorghum entrics (Sorghum bicolor (L) Moench) comprising seventeen germplasm lines, two hybrids, one relcased variety and four experimental varicties were tested at four diurnal maximum temperatures: $35,40,45$ and $50^{\circ} \mathrm{C}$. In Experiment II $25 \mathrm{~S}_{1}$ lines each from four different breeding composites of pearl millet (Pennisetum americanum ( $\left.\mathrm{I}_{+}\right)$Leeke) and in Experiment III 36 lines frum a breeding population of sorghum werc all evaluated at $45^{\circ} \mathrm{C}$. The experimental design was a randomized block with four replicates.

\section{RESULTS AND DISCUSSION}

The soil surface temperature measured in the clay pots for a 24 hour period was compared with the temperature measured at the same depth in an Alfisol field, when the water content in the top $10 \mathrm{~cm}$ in the field was $5 \%$; such conditions are characteristic of pre-sowing in the rainy season following a light rain (10-15 mm). In the pots, soil temperature increased curvilinearly after the lamps were switched on and reached a maximum between 1500 and 1800 IST (Fig. 1). Temperature then declined when the lamps were switched off. The diurnal temperature cycle in the soil surface closely followed the pattern observed in the field. The interval (1-2 h) during which the sceds or seedlings were exposed to the maximum daily temperature in the heater system was similar to that in the field. This is an improvement over the experimental tech. nique used by Scheuring et al. (1978) where the soil temperature was kept constant.

A representative sample of soil temperature measurements for one run of the heater system for each temperature is shown in Fig. 2. There was very little variation between pots; for example the coefficients of variation were 2.4, 2.3 and $2.5 \%$ for temperatures of 40,45 and $50^{\circ} \mathrm{C}$, respectively.

Soil moisture content $(0-10 \mathrm{~cm}$ depth) was measured at maximum tem. peratures (2 cm deep) of 40,45 and $50^{\circ} \mathrm{C}$ and found to fall within the range 17.3 to $17.9 \%$ in each case. Analysis of variance of the water content from 


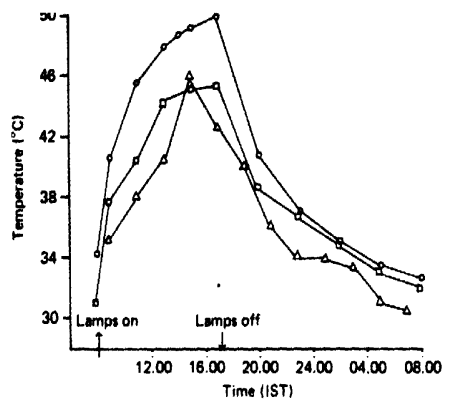

Fig. 1. Soil tempenture meaured in the pots and in the field at a depth of $2 \mathrm{~cm}$ : diumal maximum in the pots in the $50^{\circ} \mathrm{C}(0)$ and $45^{\circ} \mathrm{C}(0)$ treatments and diumal in the field $(\Delta)$. SE less than symbol size.

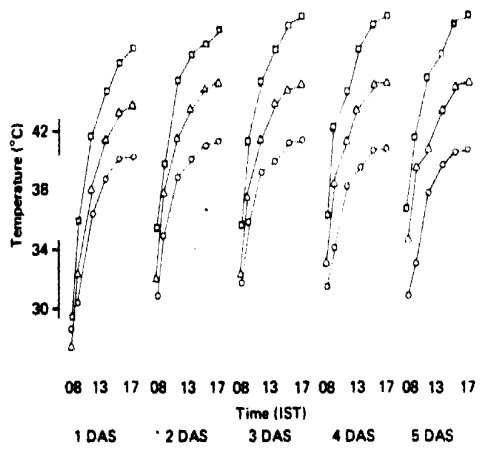

Fig. 2. Soll temperatures measured in the pots at a depth of $2 \mathrm{~cm}$ on five consecutive days after sowing (DAS): diumal maximum in the $40^{\circ} \mathrm{C}(0), 45^{\circ} \mathrm{C}(4)$ and $50^{\circ} \mathrm{C}(0)$ treatments. SE less than symbol eize.

each temperature treatment showed that this did not differ significantly on different days (1-4 DAS). However, as temperatures increased in each treatment the top centimetre of soil in the pots dried out, but this did not affect germination and emergence as moisture was available in the seed zone. In contrast to the field, there was no significant decline in soil moisture in the pots with increase in temperature; this was one of the problems encountered by 
Wilson et al. (1982). Buckle and Grant (1974) did not report the water status of the soil in their experiments with maize.

Soil crusting did not occur in any of the pots in the trials, probably because there was a continuous supply of water from the lower soil layers and no mechanical impact from raindrops (sce Soman et al., 1984).

Emergence by four DAS exceeded $80 \%$ in the $40^{\circ} \mathrm{C}$ treatment. The emergence response of the sorghum entries is shown in Table 1. The effect of both temperature and genotype, analysed after pooling the data for each temperature, was highly significant $(P<0.001)$ with considerable genotype $x$ temperature interaction $(P<0.01)$. IS 6118 was the only entry which emerged well $(60 \%)$ at $50^{\circ} \mathrm{C}$. At $45^{\circ} \mathrm{C}$ only $40 \%$ of the entries achieved $60 \%$ emergence, while at temperatures of 40 and $35^{\circ} \mathrm{C}$ corresponding figures of emergence were 87 and $96 \%$. The technique thus successfully differentiated sorghum material by ability to emerge as a function of temperaturc.

The technique provided repeatable results. For example, IS 1037 achieved

Table 1. Emergence (\%) of sorghum achieved at different diumal maximum soil temperatures (measured at a depth of $2 \mathrm{~cm}$ )

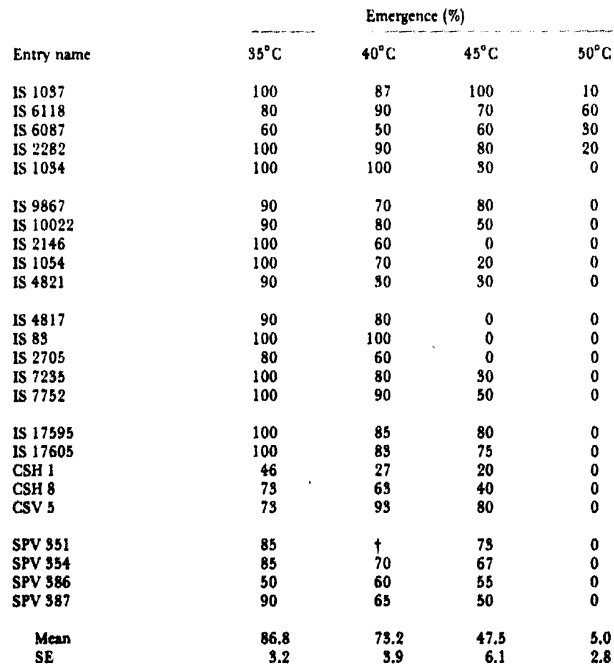


$92 \pm 3 \%, 86 \pm 4 \%$, and $86 \pm 3 \%$ emergence in three preliminary tests at $40^{\circ} \mathrm{C}$, and $\operatorname{CSH~} 6$, an entry with poor emergence at $40^{\circ} \mathrm{C}$, achieved $40 \pm 7 \%$ and $36 \pm 4 \%$ emergence in two tests at this temperature (Soman, 1981).

Soil temperature rises above $40^{\circ} \mathrm{C}$ in the semi-arid tropics during the sowing season and inhibits emergence in a number of lines. Initial experiments showed that a temperature maximum of $45^{\circ} \mathrm{C}$ gave the best selection pressure and very few lines emerged at $50^{\circ} \mathrm{C}$. The genctic differences among the lines from four pearl millet and a sorghum population measured at $45^{\circ} \mathrm{C}$ are shown in Fig. 3 .

High soil temperature affects germination and emergence in several ways. The soil temperature in the seed zone can inhibit germination itself and plumule extension can be halted at any time after germination. In these experiments, 1 when the topsoil in the clay pots was removed, many ungerminated seeds and secdlings with damaged plumules which had failed to emerge were observed. Buckle and Grant (1974) recorded similar abnormalitics with maize scedlings grown at an average soil temperature of $40^{\circ} \mathrm{C}$. In addition differences in the rate of plumule extension were observed when sorghum was grown at a range of temperatures (Soman, 1981).

157 (1)

(b)

\footnotetext{
$0-20-41-60 \quad 81-100$

$21-40 \quad 61-80$

Emergence $(x)$
}

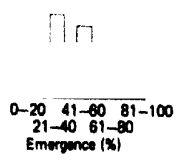

Fis. 3. Clastification of entries from four peari millet $(a, b, c, d)$ and one sorghum population (e) $c$ the bail of emergence at a soil wurface temperature of $45^{\circ} \mathrm{C}$. 
This technique has been used to classify germplasm and breeders' lines according to their performance at high (up to $50^{\circ} \mathrm{C}$ ) soil surface temperatures and shows that genotypic variation clearly exists among sorghum and pearl millet lines. Further studies using this system coupled with a more detailed biochemical analysis are required to understand better the mechanisms of inhibition of emergence by high temperature. Such studies are reported by Ougham and Stoddart (1985) in the following paper.

Acknowledgements. We are grateful to Mr D. Subramaniam of the Physical Plant Services of ICRISAT for his help in making the apparatus, Mr R. Jayachandran for setting up the trials and Dr F. R. Bidinger for his constant encouragement.

\section{REFERENCES}

Buckle, J. A. \& Grant, P. M. (1974). Effects of soil temperature on plumule growth and seedling emergence of maize (Zea mays L.). Rhodesian Joumal of Agricultural Research 12:149-161.

Garcia-Huidobro, J., Monteith, J. L. \& Squire, G. R. (1982). Time, temperature and germination of pearl millet (Pennisetum typhoides S.H.). L. Constant temperature. Joumal of Experimental Botany 33:28896.

ICRISAT (International Crops Research Institute for the Semi-Arid Tropics) (1983). Annual Report 1982. Patancheru, A.P., India: ICRISAT.

Mustain, B. C. (1981). Gemination and emergence of grain sorghum (Sorghum bicolor (L) Moench) at low and high temperatures: Maternal and hybrid effects. Ph.D. dissertation, Texas AM Univernity. Published by University Microfilms Intermational, 30/32 Mortimer St, London W1N 7RA, Enqland.

Ougham, H. J. \& Stoddar, J. L. (1985). Development of a leboratory screening technique, based on embryo protein synthesis, for the asucusment of high-temperature susceptibility during germination of Sorghum bicolor. Experimental Agriculture 21:343-355.

Peacock, J. M. (1977). The weather at Content Farm, Sebele Botawana. Dryland Farming Rescarch Scheme (DLFRS) Botswana. In Interim Scientific Report Phase II. Dryland Farming Research Scheme (DLFRS) Gaborone, Botswana Gaborone: Government Printer.

Peacock, J. M. (1982). Response and tolerance of sorghum to temperature otress, In Sorghum in the Eighties. Proceedings of the Intermotional Symposium on Sorghum, ICRISAT, 2-7 Nov. 1981, 143160. Patanchers, A.P., India: ICRISAT.

Peacock, J. M. \& Heinrich, G. M. (1984). Light and temperature responses in sorghum. In Froceedings

1 of the ICRISAT/WMO Symposium on the Agrometeorology of Sorghum and Millet in the Semi-arid Tropics, 15-19 Nov, 1982, 1-15. Patancheru, A.P., Indie: ICRISAT.

Peacock, J. M. \& Ntshole, M. R. (1976). The effect of row spacing and plant population on the growth, development, grain yield, microclimate and water use of Sorghum bicolor cv. 65D. In Initial Annual Report Phase II, Dyland Farming Research Scheme (DLFRS), Gaborone, Botswana, 31-44. Gaborone: Government Printer.

Scheuring J. F., Newton, R J. \& Miller, F. R. (1978). Selection of sorghum seedling based on high tem. perature germination. Sorghum Newsletter 21:108-109.

Soman, P. (1981). Factors affecting seed germination and seedling emergence in millet and sorghum: A report on some experimental techniques and renslts. ICRISAT Internal Report. ICRISAT, Patanchers, A.P., India: ICRISAT.

Soman, P., Bidinger, F. R., Peacock, J. M. \& Walker, T. S. (1981). Seedling establiahment - A preliminary survey taken up in Aurepally during Kharif 1981. ISCRISAT Internal Report. ICRISAT, Patancheru, A.P., Indis: ICRISAT.

Soman, P., Peacock, J. M. \& Bidinger, F. R. (1984). A field technique to screen seedling emergence of pearl millet and conghum through soil crusts. Experimental Agriculture 20:327-334.

Wileon, G. L, Raju, P. S. \& Pescock, J. M. (1982). Effect of soil tempenture on seedling emergence in sorghum. Indien Jownd of Arricultural Science 52:848-51. 